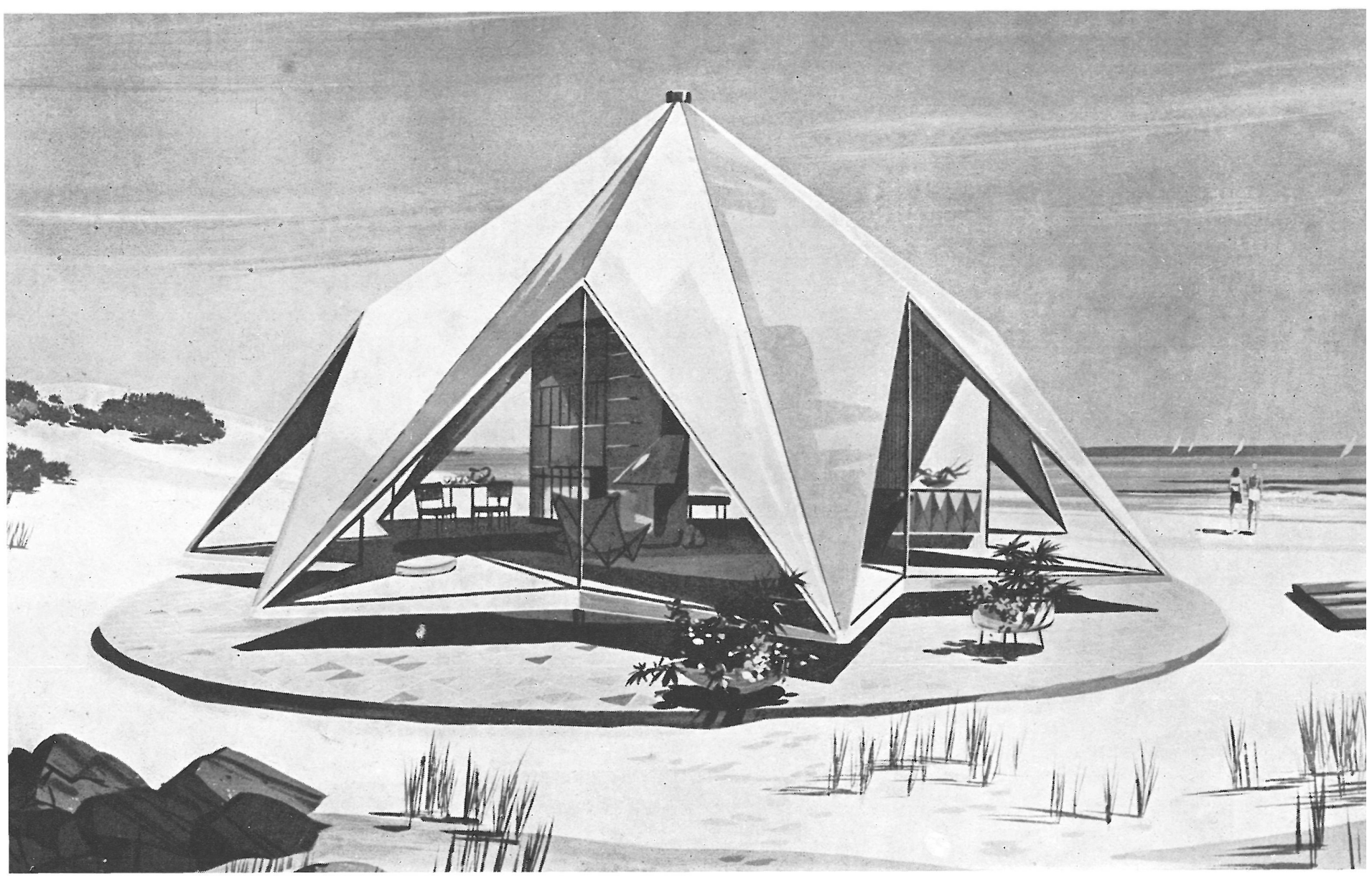

\section{caseta para la playa}

por R. M. GARRICK

$161-60$

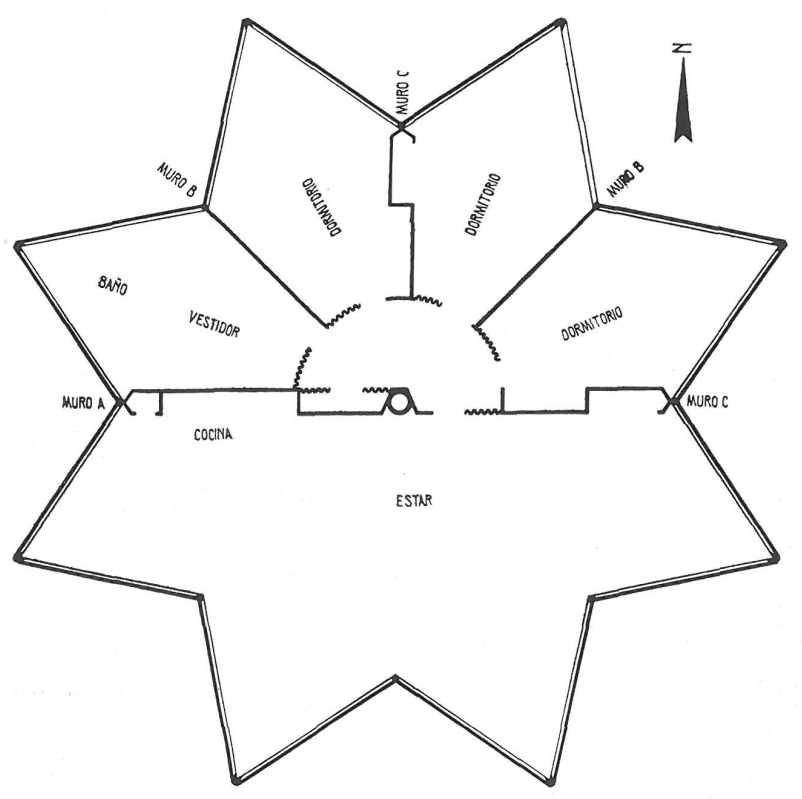

Esta encantadora muestra de caseta de baño fué diseñada por la Compañía Americana de Aluminio, bajo la dirección de la célebre asociación de arquitectos Harrison y Abramovitz.

Tiene la propiedad de poder "seguir" al sol en su marcha-como los girasoles-, y está montada, al efecto, sobre una plataforma giratoria que le permite situarse en la forma más conveniente y adecuada para sus moradores. La planta es estrellada de ocho puntas. La cubierta plegada, de colores, y los triángulos acristalados de los tímpanos le dan el aspecto de diafanidad apetecido y la hacen perfectamente accesible desde todos los puntos.

Con esta demostración se ve, una vez más, que el metal ligero puede proporcionar no sólo belleza, sino adaptarse mejor que otro a la forma de vivir y a las directrices constructivas de hoy y del futuro.

Sujeta alrededor de una columna central de aluminio, la caseta de baño se apoya sobre un círculo, de $11,30 \mathrm{~m}$ de diámetro, y está formada por piezas iguales triangulares que vienen a juntarse - dos a dos-en cada una de las puntas de la estrella.

La cubierta, inspirada tal vez en la tradicional tienda de campaña, tiene una altura libre, en el vértice y desde la base, de 4,70 metros, y los triángulos de que hemos hablado antes-piezas de cubierta-pueden colorearse para conseguir un efecto más festivo y alegre.

La circunstancia de tener abiertos todos los lados, es una consecuencia lógica de la forma de vida que suele adoptarse idealmente en la playa: espacio, sol y aire.

En cuanto a la distribución, es bien simple: la mitad de la planta pertenece al estar-comedor, con una pequeña cocina adjunta. Tres "puntas" restantes se destinan a dormitorios y la otra a vestidor y cuarto de baño.

La edificación, no de gran importancia por sus dimensiones, es realmente interesante por su solución y demuestra el interés constante de renovación de materiales, técnicas y formas. 